\title{
KOMERSIALISASI PADA PRODUKTIVITAS LEMBAGA KEUANGAN MIKRO
}

\author{
Nanette Indira Wibowo \\ Deny Dwi Hartomo \\ Fakultas Ekonomi dan Bisnis Universitas Sebelas Maret \\ email: denyhartomo@ staff.uns.ac.id
}

\begin{abstract}
The purpose of this study was to determine the effect of commercialization on the productivity of MFIs in Indonesia by using variable profitability consisting of proxies ROA, ROE, NIM and variable liabilities consisting of proxies size of the loan portfolio and leverage. The research is explanatory research with purposive sampling technique in MFIs in Indonesia to use data sources Microfinance Information Exchange from 2010-2015. The samples used in this study were 40 rural banks.

Results showed that the profitability and liabilities simultaneously significant positive effect on Yield Rate. And partially, ROE ROA NIM significant positive effect on Yield Rate with a significance level of $5 \%, 5 \%$ and $5 \%$. While the loan portfolio positive effect was not significant to Yield Rate, and leverage negative effect not significant to Yield Rate.
\end{abstract}

Keywords: productivity, microfinance institutions, profitability, liabilities

\begin{abstract}
ABSTRAK
Tujuan dari penelitian ini adalah untuk mengetahui pengaruh komersialisasi terhadap produktivitas LKM di Indonesia dengan menggunakan variabel profitabilitas yang terdiri dari proksi ROA, ROE, NIM dan variabel liabilitas yang terdiri dari proksi size of loan portofolio dan leverage.Penelitian yang bersifat explanatory research dengan teknik purposive sampling pada LKM di Indonesia dengan menggunakan sumber data Microfinance Information Exchange dari tahun 2010-2015. Jumlah sampel yang digunakan dalam penelitian ini sebanyak 40 Bank Perkreditan Rakyat.

Hasil menunjukan bahwa profitabilitas dan liabilitas secara simultan berpengaruh positif signifikan terhadap Yield Rate. Dan secara parsial, ROA ROE NIM berpengaruh positif signifikan terhadap Yield Rate dengan tingkat signifikansi $5 \%$, 5\%, dan 5\%. Sedangkan portofolio kredit berpengaruh positif tidak signifikan terhadap Yield Rate, dan leverage berpengaruh negative tidak signifikan terhadap Yield Rate.
\end{abstract}

Katakunci: produktivitas, lembaga keuangan mikro (LKM), profitabilitas, liabilitas 
Sepak terjang perbankan di Indonesia sangat pesat, hal ini didukung dengan semakin berjayanya Lembaga Keuangan Mikro (LKM) di Indonesia sampai saat ini.Lembaga Keuangan Mikro yang awalnya dianggap sebagai pertolongan kecil didalam sektor perekonomian Indonesia, namun lambat laun lembaga ini mampu menopang perekonomian dan menjadi "tulang punggung" lebih dari 33 juta pelaku usaha. Hal ini juga yang memaksa Lembaga Keuangan Mikro di Indonesia untuk tumbuh dalam bantuan pendanaan dan turut memaksa Bank Konvensional untuk terus mening katkan pelayanannya.

Kegiatan usaha LKM meliputi jasa pengembangan usaha dan pemberdayaan masyarakat, baik melalui Pinjaman atau Pembiayaan dalam usaha skala mikro kepada anggota dan masyarakat, pengelolaan Simpanan, maupun pemberian jasa konsultasi pengembangan usaha (www.ojk.go.id). Namun seiring dengan perkembangan perekonomian di Indonesia, kegiatan usaha LKM pun sudah berkembang kecakupan yang lebih luas, dengan ini apabila LKM tidak mampu memenuhi kebutuhan pendanaannya, akan membuat LKM kekurangan sumber pendanaan dalam memenuhi kebutuhan masyarakat.

Ada beberapa jenis lembaga yang tergabung didalam LKM.Seperti BMT, BKK, Koperasi, BPR, dlI. LKM saat ini juga semakin berinovasi dengan memberikan fasilitas tabungan, pinjaman dengan proses yang lebih mudah dibanding bank konvensional. Hal inilah yang membuat LKM menjadi tumpuan bagi masyarakat menengah kebawah untuk memenuhi kebutuhan kreditnya.

Saat ini pula sudah banyak BPR yang ikut dalam sektor komersial dan menarik investor internasional.Dan hal inilah yang banyak menjadi tujuan utama BPR saat ini.Mereka seperti berlomba untuk mengkomersialisasi lembaga keuangan mereka dengan sumber pendanaan mereka yang cukup kuat.Hal inilah yang membuat BPR sedikit demi sedikit merubah fokus bisnis mereka dari segmen mikro mejadi segmen yang lebih luas. Namun apabila tidak bisa mengatur pembiayaan operasional mereka, akan berakibat kerusakan sistem keuangan dan akan menyebabkan bangkrutnya BPR. Sehingga kebijakan yang diambil akan sangat mempengaruhi kinerja BPR, seperti financial distress, likuidasi, dan collapse merupakan resiko yang dapat terjadi. Sehingga perlu adanya ketepatan pengambilan kebijakan dalam megoptimalkan kinerja BPR dan meminimalisir resiko yang mungkin terjadi karena adanya komersialisasi terhadap BPR yang akan menentukan tingkat produktivitas BPR tersebut.

Penelitian ini dipilih untuk melakukan studi lebih lanjut dengan memodifikasi artikel utama penelitian yang dilakukan Halloway dan Chisty (2011). Alasan melakukan studi lebih lanjut ini adalah peneliti ingin mengetahui apakah jika dilakukan penelitian ulang dengan periode waktu yang paling akhir dan sumber data yang berbeda, hasil penelitian akan konsisten dengan penelitian sebelumnya.

\section{TELAAH PUSTAKA}

\section{Lembaga Keuangan Mikro}

Sesuai dengan namanya, LKM lebih berfokus pada keuangan dengan ruang lingkup kecil.Dengan lingkup yang terbatas ini, membatasi pula akses jangkauan LKM.Layanan yang diberikan LKM meliputi pinjaman, tabungan, asuransi, dan pengiriman uang.Kredit mikro diberikan untuk mengembangkan usaha mikro.Sehing ga dapat dilihat kebutuhan masyarakat saat ini sudah mulai berubah dari waktu ke waktu.Dengan kebutuhan yang sudah berubah dan beragam, LKM yang memang mengkhususkan untuk pembiayaan masyarakat menengah kebawah sering menggunakan metodologi non-tradisional seperti pinjaman kelompok yang tidak dipekerjakan oleh sektor keuangan formal. 


\section{Komersialisasi}

Pengertian Komersialisasi adalah kegiatan atau perbuatan yang menjadikan sesuatu sebagai barang dagangan (Departemen Pendidikan Dan Kebudayaan, 2006). Menurut KBBI komersialisasi dapat diartikan sebagai perbuatan menjadikan sesuatu sebagai barang dagangan. Komersialisasi juga bisa diartikan sebagai penataan lembaga atau kegiatan yang sepenuhnya hanya berdasar keuntungan material individu (Hartini dan Kartasapoetra, 1992). Komersialisasi bukan hanya dapat dilakukan terhadap sesuatu yang berbentuk barang, hal-hal seperti jasa atau pertunjukan juga bisa menjadi sesuatu yang diperdagangkan. Komersialisasi biasanya memberikan perubahan-perubahan terhadap hal yang menjadi komoditas tersebut.

Komersialisasi merupakan langkah yang diperlukan untuk meningkatkan kualitas LKM dalam memberikan layanan kepada masyarakat (Roberto, 2011).Tujuan utama pada komersialisasi adalah untuk meningkatkan keuntungan perusahaan. Namun meskipun komersialisasi LKM berpotensi meningkatkan performa finansial, tetapi apabila LKM harus tetap berfokus pada pembiayaan masyarakat kebawah karena dapat melemahkan upayanya dalam melayani si miskin, sehingga faktor-faktor seperti sumber daya manusia, lingkungan pasar, investasi, dapat menjadi pengaruh yang penting dalam komersialisasi ini.

Saat ini pula sudah banyak BPR yang ikut dalam sektor komersial dan menarik investor internasional. Dan hal inilah yang banyak menjadi tujuan utama BPR saat ini. Mereka seperti berlomba untuk mengkomersialisasi lembaga keuangan mereka dengan sumber pendanaan mereka yang cukup kuat. Hal inilah yang membuat BPR sedikit demi sedikit merubah fokus bisnis mereka dari segmen mikro menjadi segmen yang lebih luas. Namun apabila tidak bisa mengatur pembiayaan operasional mereka, akan berakibat kerusakan sistem keuangan dan akan menyebabkan bangkrutnya BPR. Sehingga kebijakan yang diambil akan sangat mempengaruhi kinerja BPR, seperti financial distress, likuidasi, dan collapse merupakan resiko yang dapat terjadi. Sehingga perlu adanya ketepatan pengambilan kebijakan dalam megoptimalkan kinerja BPR dan meminimalisir resiko yang mungkin terjadi karena adanya komersialisasi terhadap BPR yang akan menentukan tingkat produktivitas BPR tersebut.

\section{Kinerja Bank}

Kinerja suatu bank dapat diukur dengan melihat tingkat kesehatan suatu bank. Kesehatan dari suatu bank dapat diartikan kemampuan dari suatu bank untuk melakukan kegiatan operasional perbankan secara normal dan mampu memenuhi semua kewajibannya dengan baik menurut cara-cara yang sesuai dengan peraturan perbankan yang berlaku (Susilodkk, 2000).

Tingkat kesehatan bank penting karena kompleksitas dan profil risiko yang semakin meningkat, sebagai salah satu sarana untuk menetapkan strategi usaha di waktu yang akan datang, untuk keperluan penetapan dan implementasi startegi pengawasan Bank, dan adanya tanggung jawab pada masyarakat. Sesuai dengan Peraturan Bank Indonesia Nomor 6/10/PBI/2004 tanggal 12 April 2004 tentang Sistem Penilaian Tingkat Kesehatan Bank Umum (Lembaran Negara Republik Indonesia Tahun 2004 Nomor 38, Tambahan Lembaran Negara Nomor 4382) Bank wajib melakukan penilaian Tingkat Kesehatan Bank secara triwulanan.

Semakin meningkatnya kompleksitas usaha dan profil risiko, Bank perlu mengidentifikasi permasalahan yang mungkin timbul dari operasional Bank. Bagi perbankan, hasil akhir penilaian kondisi Bank tersebut dapat digunakan sebagai salah satu sarana dalam menetapkan strategi usaha di waktu yang akan datang sedangkan bagi Bank Indonesia antara lain digunakan sebagai sarana penetapan dan implementasi strategi pengawasan Bank oleh Bank Indonesia.

Dengan demikian kinerja perbankan merupakan gambaran prestasi yang dicapai bank dalam aspek keuangan, pemasaran, penghimpunan dan penyaluran 
dana dalam suatu periode yang biasanya diukur dengan indikator kinerja perbankan sebagai berikut:

1. Rasio Rentabilitas bank

Merupakan kemampuan bank dalam menghasilkan laba selama periode tertentu. Selain itu rasio ini bertujuan untuk mengukur tingkat efektifitas manajemen dalam menjalankan usahanya. Rasio yang dapat diukur antara lain : gross profit margin, net profit margin, return on equity, return on assets, rate return on loan interest margin on earnings assets, interest margin on loan, laverage multiplier, asssets utilization, interest expense ratio, cost of fund,cost of money, cost of loanable fund, cost of operable fund, dan cost of efficiency.

2. Rasio Likuiditas bank

Merupakan rasio yang digunakan untuk mengukur kemampuan bank dalam memenuhi kewajiban jangka pendeknya pada saat ditagih. Suatu bank dapat dikatakan likuid apabila bank dapat memenuhi semua kewajibannya, khususnya kewajiban jangka pendek yang berkaitan dengan simpanan masyarakat (simpanan, tabungan, giro) dan bank mampu memenuhi semua permohonan kredit yang layak dibiayai. Rasio yang dapat diukur antara lain: quick ratio, Loan to Deposit Ratio (LDR), assets to loan ratio, Investing policy ratio, banking ratio, investment portofolio ratio, dan cash ratio. Semakin tinggi rasio ini maka semakin likuid bank tersebut.

3. RasioSolvabilitas bank

Rasio solvabilitas merupakan rasio yang mengukur kemampuan perusahaan untuk membayar kewajiban jika pada suatu saat perusahaan dilikuidasi atau dibubarkan. Rasio ini mengukur seberapa besar perusahaan menggunakan dana dari pihak luar atau kreditor. Rasio solvabilitas yang digunakan dalam penelitian ini adalah Debt to Equity Ratio (DER).Rasio ini mengukur kemampuan perusahaan dalam membayar hutang-hutangnya dengan menggunakan ekuitas yang dimiliki.Leverage menunjukkan proporsi hutang untuk membiayai investasi. Jika sebagian besar dari total biaya perusahaan adalah biaya tetap, perusahaan itu dikatakan mempunyai leverage yang tinggi. (Brigham Dan Houston, 2001).

\section{Produktivitas Bank}

Produktivitas dijelaskan oleh Muchdarsyah (1993) sebagai ukuran efisiensi produktif, suatu perbandingan antara hasil keluaran dan masukan.Produktivitas LKMdalam penelitian diproksikan dengan Yield Rate. Yield Rate digunakan untuk mengukur konversi antara savers menjadi borrowers. Karena sebuah LKM akan lebih produktif jika dapat mengkonversi savers menjadi borrowers. Analogi mudahnya, dlihat pada bunga kredit, semakin BPR banyak memberikan pinjaman dana kepada borrowers, semakin banyak pula keuntungan yang didapat dari hasil bunga yang didapat oleh BPR.

Yield Rate dalam penelitian ini diukur dengan cara membagi borrowers per staff member dengan savers per staff member (Halloway dan Chisty, 2011). Borrowers dimaksudkan dengan personel/staff dari LKMyang bisa mendapatkan jumlah active borrowers. Dan saversdimaksudkan dengan orang yang menyimpan dananya di BPR (dalam Mix Market disebutkan bahwa savers diukur oleh depositors).

\section{Pengaruh ROA terhadap produktivitas LKMdi Indonesia}

Dari studi yang diteliti oleh Helmy Fahrizal (2013) yang berjudul Pengaruh Return On Assets (ROA), Return On Equity (ROE) Dan Investment Opportunity Set (IOS) Terhadap Nilai Perusahaan (Studi Empiris pada Perusahaan Manufaktur Jenis Consumer Goods yang Terdaftar di Bursa Efek Indonesia) menyatakan bahwa ROA memiliki hubungan terhadap nilai suatu perusahaan.

Bank Ind onesia lebih mementingkan penilaian besarnya laba berdasarkanReturn On Assets (ROA) karena Bank Indonesia lebih mengutamakan nilaiprofitabilitas suatu 
bank yang diukur dengan assets yang dananya sebagian besardari dana simpanan masyarakat. Return On Assets (ROA) adalah indikator yangakan menunjukkan bahwa apabila rasio ini meningkat maka aktiva bank telahdigunakan dengan optimal untuk memperoleh pendapatan sehingga diperkirakanROA dan kredit memiliki hubungan yang positif. Return On Assets (ROA)digunakan untuk mengukur kemampuan manajemen bank dalam memperoleh keuntungan (laba) secara keseluruhan.

ROA membandingkan laba terhadap total asset, apabila terjadi peningkatan ROA secara signifikan maka akan berpengaruh juga terhadap penyaluran kredit pada bank. Semakin besar Return On Assets (ROA) suatu bank semakin besar pula tingkat keuntungan yang dicapai bank tersebut dengan laba yang besar maka suatu bank dapat menawarkan kredit lebih banyak kepada masyarakat yang membutuhkan dana.

\section{H1. ROA memiliki pengaruh positif terhadap produktivitas LKM di Indonesia.}

\section{Pengaruh ROE terhadap produktivitas LKM di Indonesia}

Pada penelitian Halloway dan Chisty (2011) menyatakan bahwa ketika ROE meningkat, yield rate pun akan meningkat. Sehingga dapat dikatakan, semakin perusahaan menyediakan penyediaan pinjaman, semakin tinggi pula pengembalian dana modal yang lebih besar dari pembayaran pinjaman dan bunga tersebut.

Tingkat profitabilitas perusahaan digunakan Return On Equity (ROE), karena ROE mengukur kemampuan perusahaan memperoleh laba yang tersedia bagi pemegang saham perusahaan dalam bentuk penyertaan modal sendiri yang ditanamkan oleh pemegang saham. Hal ini karena Return on Equity biasa menggambarkan apakah para pemegang saham menerima pengembalian yang pantas atas investasi mereka. Alasan pemilihan Return on Equity adalah karena dengan membandingkan rasio ini dapat diketahui apakah pendapatan yang ada untuk pemegang saham lebih menarik dibandingkan perusahaan lain yang ada dalam bidang usaha sejenis.

Return On Equity sering juga dinamakan rentabilitas usaha adalah perbandingan antara jumlah laba yang tersedia bagi pemilik modal sendiri di satu pihak dengan jumlah modal sendiri yang menghasilkan laba dilain pihak (Riyanto, 2008). Atau dengan kata lain dapat dikatakan bahwa rentabilitas modal sendiri adalah kemampuan suatu perusahaan dengan modal sendiri yang bekerja didalamnya untuk menghasilkan keuntungan.Dan meningkatnya ROE, akan menurunkan pula hutang LKM pada aspek permodalan. Karena return yang diterima akan semakin tinggi, return itu dapat digunakan untuk membayar hutang LKM dengan teratur.

H2. ROE memiliki pengaruh positif terhadap produktivitas LKMdi Indonesia.

\section{Pengaruh Net I nterest Margin terhadap produktivitas LKM di Indonesia}

PengaruhNetProfitMargin dan Leverage Operasi Terhadap Tindakan Pemerataan Laba Pada Perusahaan Automotif Yang Tercatat Di Bursa Efek Indonesia, yang diteliti oleh Widiyanti Nurjanah (2010) menyatakan bahwa Net Profit Margin berpengaruh terhadap perataan laba.Net Interest Margin merupakan salah satu indikator yang penting untuk menilai suatu perusahaan. Net Interest Margin selain digunakan untuk mengukur kemampuan perusahaan dalam menghasilkan laba juga untuk mengetahui efektifitas perusahaan dalam mengelola sumber-sumber yang dimilikinya.

Rasio laba operasi bersih terhadap penjualan banyak digunakan oleh para praktisi keuangan sebagai penentu nilai (value drive) kunci yang mempengaruhi penilaian atas sebuah perusahaan.Dilihat dari sisi borrowers, dengan rasio laba operasi bersih yang tinggi memberikan keyakinan perusahaan mampu meminjamkandana kenasabah.Selanjutnya dari sisi savers, dengan melihat laba operasi yang tinggi pada perusahaan tersebut, akan mempengaruhi penyimpan dana untuk ikut meminjam dananya pada perusahaan tersebut, dengan kondisi ini akan meningkatkan produktivitas LKM tersebut.

H3. Net Interest Margin memiliki pengaruh positif terhadap produktivitas LKM di Indonesia. 


\section{Pengaruh Portofolio Kredit terhadap produktivitas LKM di Indonesia}

Penelitian Halloway dan Chisty (2011) menemukan hasil yang positif mengenai pengaruh portofolio kredit terhadap produktivitas LKM. Hal ini juga dapat dikatakan, dengan semakin tingginya perusahaan memberikan jumlah pinjaman, semakin ting $i$ pula tingkat pengembalian pinjaman dan bunga yang diterima perusahaan, sehingga perusahaan akan menurunkan resiko bangkrut dan meningkatkan return.

Dilihat dari sisi borrowers, peminjam juga akan yakin dalam meminjam dana ke perusahaan dengan tingkat size of loan portofolio tinggi karena peminjam yakin bahwa perusahaan kuat karena mampu meminjamkan dana kenasab ah dengan jumlah yang besar. Dilihat dari sisi savers, dengan melihat kekuatan permodalan pada perusahaan tersebut, akan ikut mempengaruhi penyimpan dana untuk ikut meminjam dananya pada perusahaan tersebut. Dengan konversi savers menjadi borrowers ini, akan meningkatkan produktivitas LKM tersebut.

H4. Portofolio Kredit memiliki pengaruh positif terhadap produktivitas LKM di Indonesia

\section{Pengaruh leverage terhadap produktivitas LKM di Indonesia}

Pada penelitian Halloway dan Chisty (2011), menggunakan data LKM yang ada di Negara Amerika Tengah, Asia, dan Afrika Timur dan menghasilkan kesimpulan bahwa leverage berpengaruh negative terhadap produktivitas yang berarti bahwa penggunaan hutang yang semakin besar yang digunakan oleh LKM sebagai sumber dananya. Hal ini akan menurunkan produktivitas LKM. Dan hasil juga menunjukkan bahwa leverage berpengaruh positif terhadap resiko perusahan. Hal ini selaras dengan yang pertama, bahwa semakin tinggi leverage, semakin tinggi pula resko perusahaan dalam penggunaan hutang tersebut, atau kata lain bisa dikatakan lebih mudah untuk bangkrut. Hal ini karena pendanaan dari hutang lebih tinggi daripada modal sendiri (equity).

Debt to Equity Ratio (DER) yaitu total kewajiban dibagi total ekuitas. (Riyanto, 2008) menunjukkan pengukur tingkat penggunaan utang (total hutang) terhadap modal yang dimiliki perusahaan. Apabila biaya yang ditimbulkan oleh pinjaman (cost of debt) lebih kecil daripada biaya modal sendiri (cost of equity), maka sumber dana yang berasal dari pinjaman atau hutang akan lebih efektif dalam menghasilkan laba (meningkatkan produktifitas), demikian sebaliknya (Brigham dan Houston, 2001). Karena penggunaan hutang yang semakin tinggi, pendapatan yang akan diterima perusahaan juga akan terpotong banyak untuk membayar hutang dan bunga.

H5. Leverage memiliki pengaruh negative terhadap produktivitas LKM di Indonesia.

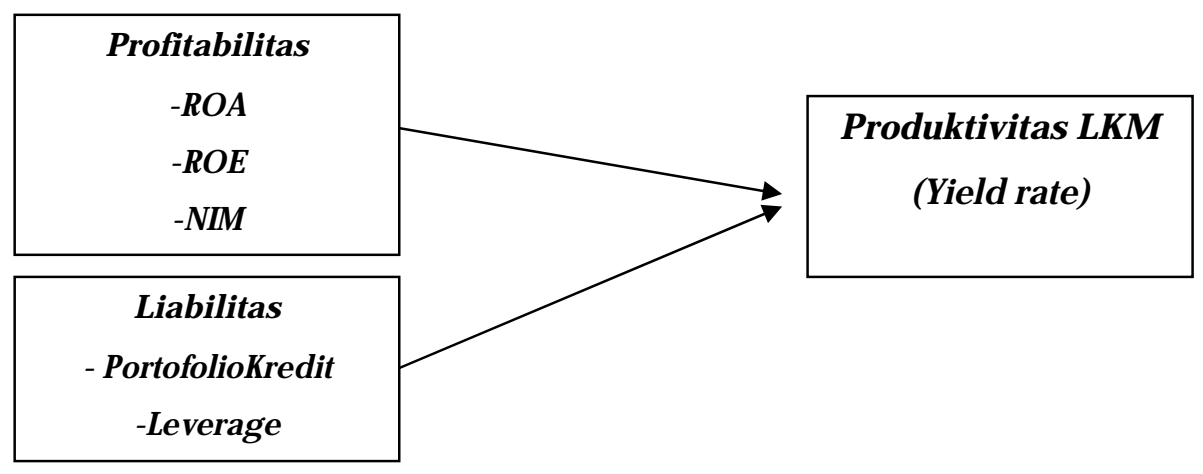

Gambar 1. Kerangka Pemikiran 


\section{METODE PENELITIAN}

\section{Populasi dan Sampel}

Populasi yang digunakan dalam penelitian ini adalah seluruh LKM termasuk didalamnya BPR di wilayah Indonesia yang terdaftar di Mix Market periode waktu dari tahun 2010-2015. Metode sampling yang digunakan adalah dengan menggunakan purposive sampling dengan tidak membedakan sample, dengan pemilihan perusahaan terlebih dahulu, lalu dilihat tahun yang tersedia.

\section{Jenis dan Sumber Data}

Data yang digunakan dalam penelitian ini adalah data sekunder yang dikumpulkan dengan metode sortir sesuai kriteria penelitian terhadap lembaga keuangan yang terdaftar di Mix Market Indonesia periode waktu 2010-2015 (www.mixmarket.org).Untuk beberapa variabel, data yang ada masih merupakan data mentah pada laporan keuangan sehingga masih perlu diolah kembali untuk menjadi data yang siap pakai.

\section{Definisi Operasional}

1. Variable dependen

Yaitu variable yang dipengaruhi variable lain yang sifatnya independen. Dalam penelitian ini variable dependen adalah yield rate sebagai proksi dari produktivitas LKM. (Halloway dan Chisty, 2011).

\section{Yield rate $=$ Borrowers per staff member Savers per staff member}

2. Variable independen

Yaitu variable yang mempengaruhi atau mengakibatkan masalah lain terjadi.

Dalam penelitian ini yang menjadi variable independen adalah :

a. ROA Return on asset (ROA) digunakan untuk mengukur efektifitas perusahaan didalam menghasilkan keuntungan dengan memanfaatkan aktiva yang dimilikinya.

\section{ROA $=$ Netincome \\ Average Fixed Assets}

b. ROE merupakan rasio yang digunakan untuk mengukur laba bersih setelah pajak dengan modal sendiri yang menunjukkan efisiensi penggunaan modal sendiri.

\section{ROE $=$ Netincome Total equity}

c. Net Interest Margin (NIM) digunakan untuk mengukur presentase laba bersih (setelahpajak) terhadap penjualan bersih perusahaan.

\section{Net Interest Margin $=$ Net income \\ Net Sales}

d. Portofolio Kredit merupakan penyaluran kredit yang diukur dengan indikator Yield on Gross Portofolio.

\section{Yield on Gross Portofolio = interest and fees on loan portofolio Loan portofolio}

e. Leverage yang digunakan dalam penelitian ini diukur dengan debt to equity ratio (DER). Rasio ini digunakan untuk menggambarkan kebijakan hutang perusahaan.

$$
\text { LVG }=\text { DER }=\frac{\text { Total debt }}{\text { Total equity }}
$$




\section{HASI L DAN PEMBAHASAN}

\section{Analisis Deskriptif}

Berdasarkan tabel 1 diketahui bahwa statistik deskriptif terdiri mean (rerata) tertinggi dari semua variabel adalah size of loan portfolio sebesar 26,207, median terting gi pada variabel portfolio kredit sebesar $29,955 \%$, mode terting gi pada variabel Debt to equity ratio (DER) sebesar 3,45\%, dan Standar deviasi terting gi adalah portfolio kredit sebesar $20,16 \%$.

Tabel 1. Statistik Deskriptif Variabel Penelitian

\begin{tabular}{|c|c|c|c|c|c|c|}
\hline & Mean & Median & Mode & $\begin{array}{c}\text { Std. } \\
\text { Deviation }\end{array}$ & $\underset{\mathrm{m}}{\operatorname{Minimu}}$ & Maximum \\
\hline Yield Rate & .91600 & .81500 & 1.000 & .878094 & .112 & 3.250 \\
\hline DER & 4.0235 & 4.0100 & $3.45^{\mathrm{a}}$ & 1.60358 & .93 & 6.99 \\
\hline ROE & .78379 & .34000 & $.060^{\mathrm{a}}$ & 2.050619 & -6.880 & 5.460 \\
\hline ROA & .74105 & .44250 & $.231^{\mathrm{a}}$ & 1.136372 & -2.230 & 3.450 \\
\hline $\begin{array}{l}\text { Yield on Gross } \\
\text { Portfolio }\end{array}$ & 26.20700 & 29.95500 & $2.880^{\mathrm{a}}$ & 20.162197 & .780 & 100.000 \\
\hline Net Margin & 2.98825 & 2.49500 & 2.340 & 7.677896 & -12.890 & 23.340 \\
\hline
\end{tabular}

\section{Uji Normalitas}

Berdasarkan pada hasil pengujian normalitas dengan menggunakan dengan uji normalitas kolmogorov-smirnov diperoleh nilai residual asymp sig ( 2 tailed) sebasar 0,185 , dengan hasil ini maka nilai asymp sig (2 tailed) $=0,185>0,05(5 \%)$ maka dapat disimpulkan bahwa distribusi semua data adalah berdistribusi normal untuk semua variabel yang digunakan.

Tabel 2. Hasil Uji Normalitas (One Sample Kolmogorov-Smirnov Test)

\begin{tabular}{ccc}
\hline Variabel & Nilai (Sig) & Kesimpulan \\
\hline Residual & $1,091(\mathrm{Sig}=0,185)$ & Normal \\
\hline Sumber: data yang diolah $(2016)$ &
\end{tabular}

\section{Uji Multikolinieritas}

Dari tabel 3 terlihat bahwa semua nilai VIF dari hasil regresi parsial masih dibawah 10. Dapat disimpulkan bahwa dalam persamaan bebas dari masalah multikolinearitas

Tabel 3.Hasil Uji Multikolinieritas

\begin{tabular}{ccc}
\hline Variabel & VIF & Kesimpulan \\
\hline DER & 1.107 & Tidak Ada Multikolinierietas \\
ROE & 3.001 & Tidak Ada Multikolinierietas \\
ROA & 2.498 & Tidak Ada Multikolinierietas \\
Yield on Gross Portfolio & 1.693 & Tidak Ada Multikolinierietas \\
Net Margin & 1.241 & Tidak Ada Multikolinierietas \\
\hline
\end{tabular}

Sumber: data yang diolah (2016)

\section{Uji Autokorelasi}

Adapun hasil perhitungan Durbin Watson diperoleh nilai Durbin Watson sebesar 1,91. Nilai ini berada pada daerah $1,7899<d<2,2101$, sehingga dapat disimpulkan bahwa pada data tersebut telah berada pada daerah pengujian tidak mempunyai autokorelasi. 
Tabel 4. Hasil Uji Autokorelasi

\begin{tabular}{|c|c|c|c|c|c|}
\hline Model & $\mathrm{R}$ & $\mathrm{R}$ Square & $\begin{array}{c}\text { Adjusted R } \\
\text { Square }\end{array}$ & $\begin{array}{c}\text { Std. Error of } \\
\text { the Estimate }\end{array}$ & $\begin{array}{c}\text { Durbin- } \\
\text { Watson }\end{array}$ \\
\hline 1 & $.592^{\mathrm{a}}$ & .285 & .149 & .899546 & 1.910 \\
\hline
\end{tabular}

Sumber: data yang diolah (2016)

\section{Uji Heterokedastisitas}

Dari hasil perhitungan Uji Heterokedastisitas ternyata dalam model regresi tersebut semua menunjukan t-hitung $<$ t-tabel atau signifikansi $>0,05$, sehingga dapat disimpulkan bahwa dalam model regresi ini tidak terjadi masalah heterokedastisitas.

Tabel 5. Hasil Uji Heteroskedastisitas

\begin{tabular}{crrl}
\hline Variabel & $\begin{array}{r}\text { T- } \\
\text { Hitung }\end{array}$ & Sig. & Kesimpulan \\
\hline DER & 1.263 & .215 & Tidak ada heteroskedastisitas \\
ROE & -1.021 & .314 & Tidak ada heteroskedastisitas \\
ROA & .940 & .354 & Tidak ada heteroskedastisitas \\
Yield on Gross Portfolio & .409 & .685 & Tidak ada heteroskedastisitas \\
Net Margin & -.173 & .864 & Tidak ada heteroskedastisitas \\
\hline
\end{tabular}

Sumber: data yang diolah (2016)

\section{Uji Koefisien Determinasi (Uji $\mathbf{R}^{\mathbf{2}}$ )}

Dari hasil estimasi diperoleh nilai Adjusted $R^{2}$ sebesar 0,149 (14,9\%), sehing a variabel dependen (Yield rate) sebesar 14,9\% dapat dijelaskan oleh variabel independen yang dimasukkan dalam model yaitu Return on Asset (ROA), Return on equity (ROE), Net Interest Margin (NIM), portfolio kredit (GPF), dan leverage (DER)). Sedangkan sisanya sebesar $85,1 \%$ dipengaruhi oleh variabel yang tidak dijelaskan dalam model atau selain keempat variabel tersebut.

\section{Uji-F Statistik}

Dari hasil estimasi, diperoleh nilai $F$ hitung sebesar 9,632 dengan tingkat signifikansi 0,006 . Nilai ini signifikan secara statistik, karena tingkat signifikansinya di bawah 0,05 yang berarti variabel-variabel independennya secara bersama-sama berpengaruh terhadap variabel dependen. Hal ini juga berarti bahwa Return on Asset (ROA), Return on equity (ROE), Net Interest Margin (NIM), portfolio kredit (GPF), dan leverage (DER) mempunyai pengaruh secara bersama-sama terhadap variabel Yield Rate (YR) didalam analisis regresinya.

Tabel 6. Hasil Analisis Regresi

\begin{tabular}{crrrr}
\hline Variabel & $\begin{array}{c}\text { Koef } \\
\text { Regresi }\end{array}$ & thitung & Sig. & \\
\hline Konstanta & .724 & 1.617 & 0.115 & TidakSignifikan \\
ROA & .652 & 2.670 & 0.041 & Signifikan \\
ROE & .350 & 2.502 & 0.042 & Signifikan \\
Net Margin (NIM) & .006 & 2.309 & 0.046 & Signifikan \\
Yield on G ross Portfolio & .007 & 0.756 & 0.455 & Tidak Signifikan \\
(GPF) & & & & \\
DER & -.037 & -0.389 & 0.700 & Tidak Signifikan \\
\hline
\end{tabular}

Variabel Dependen: Yield rate

Sumber: data yang diolah (2016) 


\section{Pengaruh ROAterhadap Produktivitas LKM di Indonesia}

ROA mempunyai nilai koefisien regresi sebesar 0,652. Tanda koefisien regresi ini adalah positif. Sedangkan nilai t-hitung $=2,67$ yang tingkat signifikansi 0,041 (nilai sig $<0,05)$. Dengan hasil ini ROA signifikan secara statistik dan berpengaruh positif terhadap Yield rate.Hal ini menunjukkan bahwa peningkatan ROA akan meningkatkan Yield rate.

Menurut Petronila, dkk dalam Wahidahwati (2002) profitabilitas merupakan gambaran dari kinerja manajemen dalam mengelola perusahaan. Ukuran profitabilitas dapat berbagai macam seperti : laba operasi, laba bersih, tingkat pengembalian investasi/aktiva, dan tingkat pengembalian ekuitas pemilik. Ang dalam Wahidahwati (2002) mengungkapkan bahwa profitabilitas atau rasio rentabilitas menunjukkan keberhasilan perusahaan dalam menghasilkan keuntungan.Keuntungan yang layak dibagikan kepada pemegang saham dan penabung adalah keuntungan setelah bunga dan pajak.Semakin besar keuntungan yang diperoleh semakin besar kemampuan perusahaan untuk membayarkan dividennya.Jadi, profitabilitas menjadi pertimbangan penting bagi investor (penabung) dalam keputusan investasinya.

\section{Pengaruh ROE terhadap Produktivitas LKM di Indonesia}

ROE mempunyai nilai koefisien regresi sebesar 0,350. Tanda koefisien regresi ini adalah positif. Sedangkan nilai t-hitung $=2,502$ yang tingkat signifikansi 0,042 (nilai sig < 0,05). Dengan hasil ini ROE signifikan secara statistik dan berpengaruh positif terhadap Yield Rate. Hal ini menunjukkan bahwa peningkatan ROE akan meningkatkan Yield rate, sehinggaprofitabilitas adalah faktor yang memberikan kebebasan dan fleksibelitas kepada manajemen untuk melakukan dan mengungkapkan kepada pemegang saham program tanggung jawab sosial secara lebih luas (Heinze dalam Florence, et al., 2004).

Hubungan antara profitabilitas perusahaan dengan pengungkapan tanggungjawab sosial perusahaan telah menjadi anggapan dasar untuk mencerminkan pandangan bahwa reaksi sosial memerlukan gaya manajerial. Sehingga semakin tinggi tingkat profitabilitas perusahaan maka semakin besar pengungkapan informasi sosial dan penekanan resiko usaha (Bowman, dkk dalam Anggraini, 2006).Terkait dengan penelitian, ketika ROE meningkat maka yield rate juga meningkat semakin banyaknya pengembalian dana modal, akan menurunkan hutang LKM ke luar, dan meningkatkan produktivitas LKM yang terkait dengan mengkonversi savers menjadi borrowers. Dengan kondisi ini maka LKM akan memberikan pinjaman lebih merata bagi para borrowers dengan mendapatkan profit dari pembayaran bunga.

\section{Pengaruh Net I nterest Margin terhadap Produktivitas LKM di Indonesia}

Net Interest Margin (NIM) mempunyai nilai koefisien regresi sebesar 0,006.Tanda koefisien regresi ini adalah positif. Sedangkan nilai t-hitung $=2,309$ yang tingkat signifikansi 0,046 (nilai sig < 0,05). Dengan hasil ini Net Interest Margin (NIM) signifikan secara statistik dan berpengaruh terhadap Yield rate.Hal ini menunjukkan bahwa peningkatan Net Interest Margin (NIM) akan meningkatkan Yield rate.Net interest margin menunjukkan rasio antara laba bersih setelah pajak atau net income terhadap total penjualannya. Rasio ini mengukur kemampuan perusahaan menghasilkan pendapatan bersihnya terhadap total penjualan yang dicapai (Weston dkk, 1997).

Net interest margin menunjukkan ukuran (dalam hal ini rasio) kemampuan perusahaan dalam menghasilkan pendapatan bersihnya (dalam hal ini net income after tax) terhadap total penjualan (bersih) yang dicapai.Semakin tinggi rasio net income yang dicapai oleh perusahaan terhadap penjulan bersihnya menunjukkan semakin efektif operasional perusahaan dalam menghasilkan laba bersihnya.Dengan meningkatnya rasio ini menunjukkan semakin baik kinerja perusahaan.Dengan demikian hubungan antara rasio Net interest margin dengan kinerja perusahaan 
adalah positif.Nilai Net interest margin yang semakin tinggi maka berarti semakin efisien biaya yang dikeluarkan, yang berarti semakin besar tingkat kembalian keuntungan bersih (Ang, 1997).

\section{Pengaruh Portofolio Kredit terhadap Produktivitas LKM di Indonesia}

Portofolio Kreditmempunyai nilai koefisien regresi sebesar 0,007.Tanda koefisien regresi ini adalah positif. Sedangkan nilai t-hitung $=0,756$ yang tingkat signifikansi 0,455 (nilai sig $>0,05$ ). Dengan hasil ini Portofolio kredit tidak berpengaruh terhadap Yield rate.Hasil penelitian ini sama dengan penelitian Chisty \& Halloway (2011), samasama positif namun penelitian penulis tidak berpengaruh terhadap Yield Rate.

Semakin perusahaan menempatkan kredit-kredit produktifnya dengan baik, semakin perusahaan mendapatkan return yang tinggi karena tingkat pengembalian kredit yang tinggi, dan tidak hanya itu, namun juga bunga atas pengembalian kredit yang besar juga. Return yang meningkatpun sudah tentu akan meningkatkan konversi dari savers menjadi borrowers, sehingga produktivitas LKM juga dapat dikatakan meningkat. Namun hal itupun nyatanya tidak mempengaruhi besar kecilnya kredit yang disalurkan oleh LKM kepada nasabah.

\section{Pengaruh Leverage terhadap Produktivitas LKM di Indonesia}

Dept to equity(DER) mempunyai nilai koefisien regresi sebesar $-0,037$. Sedangkan nilai t-hitung $=0,389$ yang tingkat signifikansi 0,700 (nilai sig $>0,05$ ). Tanda koefisien regresi ini adalah negatif.Dengan hasil ini Dept to equity(DER)tidak berpengaruh terhadap Yield rate.Hal tersebut menunjukkan bahwa besar kecilnya Dept to equity (DER)tidak memberikan dampak terhadap besar kecilnya Yield Rate.Leverage(DER) adalah rasio antara jumlah jaminan dan dana yang dipinjam yang dialokasikan oleh perusahaan. Rasio ini digunakan untuk mengukur seberapa jauh perusahaan menggunakan hutang. Semakin besar rasio leverage maka semakin buruk keadaan keuangan sebuah perusahaan. Hal ini disebabkan semakin besarnya pendanaan perusahaan yang berasal dari hutang.

Namun hasil yang tidak signifikan ini disebabkan oleh modal yang dimiliki perusahaan bukanlah termasuk dalam modal pinjaman, melainkan modal yang tidak produktif atau juga modal dari para investor yang tertarik untuk menanamkan saham diperusahaan tersebut. Hal itu juga membuat perusahaan tidak bisa menyalurkan dana tersebut kepada nasabah peminjam, sehingga return perusahaan juga akan berkurang.Selain itu, pinjaman dari luar yang dilakukan LKM juga digunakan untuk membiayai kebutuhan-kebutuhan operasional perusahaan dan pinjaman nasabah yang termasuk kredit macet. Hal ini juga tentu saja dapat menurunkan return perusahaan. Namun bagaimanapun, besar kecil proporsi hutang yang dimiliki LKM, tidak berpengaruh terhadap produktivitas LKM.

\section{SIMPULAN}

\section{Simpulan}

Penelitian ini tidak konsisten dengan penelitian yang dilakukan oleh Halloway dan Chisty (2011) dengan sampel microfinance di berbagai negara (crosscountry).Temuan pada penelitian ini diperoleh bahwa apabila semakin komersial LKM di Indonesia (ditunjukkan dengan profitabilitas yang meningkat) maka semakin produktif LKM tersebut. Ukuran produktif dalam penelitian ini adalah peminjam (borrowers) lebih banyak dari pada penabung (savers).

Secara simultan, variabel ROA,ROE,Net Interest Margin,portfolio kredit, dan leverageberpengaruh positif dan signifikan terhadapproduktivitas Lembaga Keuangan Mikro (LKM).Secara parsial, hubungan positif dan signifikan antara ROA terhadap produktivitas LKM, hubungan positif dan signifikan antara ROE terhadap produktivitas 
LKM, hubungan positif dan signifikan antara Net Interest Margin terhadap produktivitas LKM, hubungan positif dan tidak signifikan antara portfolio kredit terhadap produktivitas LKM, terdapat hubungan negatif dan tidak signifikan antara leverageterhadap produktivitas LKM.

\section{Implikasi Penelitian}

Bagi manajemen, Selanjutnya hasil penelitian ini dapat digunakan sebagai bahan pertimbangan dalam pengambilan keputusan untuk menentukan alternatif pendanaan LKM yang tepat pada kebijakan struktur modal di masa yang akan datang sehingga kebijakan yang akan diterapkan dapat meningkatkan produktivitas yang lebih optimal. Manajemen diharapkan dapat meningkatkan profitabilitas sehingga berdampak pada meningkatnya produktifitas.

Terkait dengan hasilportfolio kredit"tidak signifikan" berarti perusahaan dapat memberikan kredit yang besar kepada para nasabah dengan cermat agar terhindar dari kredit macet. Sehingga perusahaan akan mendapatkan kembalian kredit dan bunga kredit itu sendiri.Dengan hasil leverage (DER) "tidak signifikan", berarti perusahaan dapat mengambil hutang yang besar sebagai tambahan modal operasional dari perusahaan karena hal tersebut tidak mempengaruhi tingkat produktivitas LKM, namun juga harus mempertimbangkan pendapatan perusahaan sehingga pada saat jatuh tempo pengembalian hutang dapat dipenuhi dengan baik.

\section{Keterbatasan dan Saran Penelitian}

Penelitian ini hanya menguji lima (5) proksi komersialisasi yang mempengaruhi yield rate LKM, yaitu ROA,ROE,Net Interest Margin,portfolio kredit, dan leverage. Untuk penelitian selanjutnya dapat menambah faktor biaya operasional karena profitabilitas yang tinggi kemungkinan disebabkan oleh efisiensi dari biaya. Penilitan ini juga tidak melihat faktor persaingan yang ada, sehingga faktor tersebut juga dapat dipertimbangkan.

\section{DAFTAR PUSTAKA}

Anggraini, Fr. Reni Retno. 2006. Pengungkapan Informasi Sosial Dan Faktor-Faktor Yang Mempengaruhi Pengungkapan Informasisosial Dalam Laporan Keuangan Tahunan (Studi Empiris Pada Perusahaan-Perusahaan Yang Terdaftar Di Burs Efek Jakarta). Ikatan Akuntan Indonesia: Simposium Nasional Akuntansi.

Bank Indonesia. 2004. Peraturan Bank Indonesia No. 6 / 10/ PBI / 2004 Tentang Sistem Penilaian Kesehatan Bank Umum. www.bi.go.id

Bank Indonesia. 2004. Surat Edaran Bank Indonesia No. 6/23 / DPNP Perihal Sistem Penilaian Tingkat Kesehatan Bank Umum Tanggal 31 Mei.Bank Ind onesia. Jakarta.

Brigham, Eugene F Dan Houston, Joel F. 2001. Manajemen KeuanganBuku 1 (terjemahan). Jakarta: Erlangga.

Brigham, Eugene F Dan Houston, Joel F. 2001. Manajemen KeuanganBuku 2 (terjemahan). Jakarta: Erlangga.

Departemen Pendidikan Dan Kebudayaan. 2006. Kamus Besar Bahasa Indonesia. Jakarta: Balai Pustaka

Fahrizal, Helmy. 2013. Pengaruh Return On Assets (ROA), Return On Equity (ROE) Dan Investment Opportunity Set (IOS) Terhadap Nilai Perusahaan (Studi Empiris Pada Perusahaan Manufaktur Jenis Consumer Goods Yang Terdaftar Di Bursa Efek Indonesia). Jakarta: Universitas Islam Negeri Syarif Hidayatullah.

Halloway, Rashid. Chisty, Muhammad. 2011. Commercialization And Changes In Capital Structure In Microfinance Institutions. Journal Of Managerial Finance Vol. 37 No. 5. 
Hartini dan Kartasapoetra, G. 1992. Kamus Sosiologi Dan Kependudukan. Jakarta: Bumi Aksara.

Muchdarsyah, Sinungan. 1993. Dasar-Dasar Manajemen Kredit. Jakarta: Bumi Aksara.

Nurjanah, Widiyanti. 2010. Pengaruh Net Profit Margin Dan Leverage Operasi Terhadap Tindakan Pemerataan Laba Pada Perusahaan Automotif Yang Tercatat Di Bursa Efek Indonesia. Surabaya: Universitas Pembangunan Nasional "Veteran" Jawa Timur.

Riyanto, Bambang. 2008. Dasar-Dasar Pembelanjaan Perusahaan. Cetakan Keenam, Edisi Keempat. Yogyakarta: BPFE-Yogyakarta

Roberto, Akyuwen. Suthapa, I Dewa Gede. 2011. Teori Keuangan Mikro Di Indonesia. Yogyakarta: Sekolah Pascasarjana UGM.

Susilo, Y. Triandaru A, Sigit.Santoso, Totok Budi. 2000. Bank Dan LembagaKeuangan Lainnya. Jakarta: Salemba Empat.

Wahidahwati. 2002. Pengaruh Kepemilikan Manajerial Dan Kepemilikan Institusional Pada Kebijakan Hutang Perusahaan: Sebuah Perspektif Theory Agency.Jurnal Riset Akuntansi Indonesia, Vol. 5 No. 1, Januari: 1-16.

Weston, J.F. Dan Copland, T.E. 1997. Manajemen Pendanaan. Edisi 9 (terjemahan). Jakarta: Penerb it Bina Rupa Aksara.

www.ojk.go.id

www.mixmarket.org/mfi/country/indonesia 
Jurnal Bisnis \& M anajemen

Vol. 17, N o. 1, 2017 : 11 - 24 